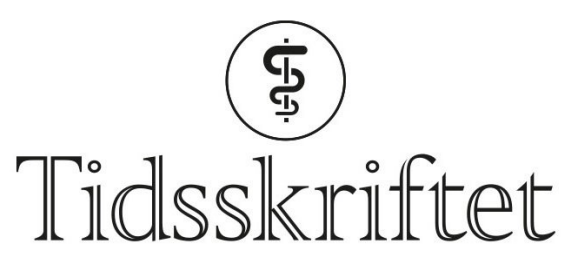

DEN NORSKE LEGEFORENING

\title{
Statistikk og annen løgn
}

KOMMENTAR

\section{TONJE HELLE FLO}

E-post:Tonje.Flo@grimstad.kommune.no

Tonje Helle Flo er sykehjemslege, tidligere assistentlege ved medisinsk avdeling. Ingen oppgitte interessekonflikter.

Dag Bratlid vurderer antall liggedøgn for inneliggende pasienter som eneste indikator på mengde arbeid for legen (1). En faktor som ikke beskrives, er hvor stort antall innleggelser som fordeles på antall liggedøgn, altså hvor mange pasienter som skrives inn og ut. Å ha én pasient som skrives ut etter fem døgn på sykehus, gir på ingen måte tilsvarende arbeidsmengde som å legge inn og skrive ut fem pasienter med opphold på ett døgn hver.

\section{LITTERATUR:}

1. Bratlid D. Legers tid til pasientarbeid og pasienters tid med legen. Tidsskr Nor Legeforen 2018; 138: 113 $-8$.

Publisert: 16. februar 2018. Tidsskr Nor Legeforen. DOI: 10.4045/tidsskr.18.0104

(C) Tidsskrift for Den norske legeforening 2020. Lastet ned fra tidsskriftet.no 